\title{
Phase Structure, Wear Resistance and Antimicrobial Response of Austenitic Stainless Steels 316 by Sputtering Cu during Plasma Nitriding and PECVD of Silicon Nitride
}

\author{
Ahmad Reza Rastkar
}

Laser and Plasma Research Institute, Shahid Beheshti University, G. C., Evin, Tehran 1983969411, Iran

\begin{abstract}
The surface of stainless steel $316 \mathrm{~L}$ was plasma nitrided and subsequently deposited with silicon nitride from tetraethylorthosilicate (TEOS): $\mathrm{H}_{2}: \mathrm{N}_{2}$ gas mixtures by plasma enhanced chemical vapor deposition (PECVD). A copper mesh was employed to sputter copper atoms onto the surface during the two processes to consider its effect on the microstructure, tribology and antibacterial response of hard surface layers.

The surface layers were characterized using XRD, optical and SEM microscopy, EDX analysis, microhardness test, pin-on-disc wear tests and microbial viability test. $\alpha-\mathrm{Si}_{3} \mathrm{~N}_{4}$ was found on the top surfaces of two steps processed stainless steel $316 \mathrm{~L}$. $\mathrm{Fe}_{2-3} \mathrm{~N}, \mathrm{Fe}_{4} \mathrm{~N}$ and $\mathrm{CrN}$ were identified in the compound layers. The overall thickness of the surface layers were more than $60 \mu \mathrm{m}$. The two step treatments improved the hardness up to $1600 \mathrm{HV} 0.1$. The combination of plasma nitriding (with Cu sputtering) and PECVD of silicon nitride compound (with Cu sputtering) of SS $316 \mathrm{~L}$ resulted in superior high hardness, 3 times lower friction and 10 times higher wear resistance of treated surfaces if compared to those of conventional plasma nitrided surfaces.
\end{abstract}

$\mathrm{Cu}$ addition to single plasma nitriding resulted in an effective reduction of $100 \%$ of Escherichia coli (E. coli) within 2 to $3 \mathrm{~h}$. However the bacteria viability after the two step processes with $\mathrm{Cu}$ addition diminished to zero in 3.5 to $4 \mathrm{~h}$. The antimicrobial response of the surfaces depends mainly on the $\mathrm{Cu}$ action and does not interfere with the wear resistance of the surfaces.
Received on 10-09-2014 Accepted on 12-10-2014 Published on 30-10-2014

Keywords: $\alpha-\mathrm{Si}_{3} \mathrm{~N}_{4}$, E. coli, Friction, Hardness, PECVD.

\section{INTRODUCTION}

Stainless steels are increasingly utilized in hospitals and food industries due to their good corrosion resistance in addition to a combination of strength and ductility. To improve the people's living level and public awareness on safety during daily life, wear resistant and antibacterial surfaces of stainless steels could be used to prevent the spread of infections during the life of medical instruments and implants $[1,2]$.

Copper $(\mathrm{Cu})$ and silver $(\mathrm{Ag})$ are being increasingly used as bactericidal materials in industries and public health involving materials. $\mathrm{Cu}$ has been added to the bulk and surface of stainless steels to enhance the ability of bacteria killing [1, 2]. $\mathrm{Cu}$ is cheaper than $\mathrm{Ag}$ in an industrial scale and it is easier to be added to stainless steel during its production. If the distribution of $\mathrm{Cu}$ particles in stainless steel occurs in nano

\footnotetext{
"Laser and Plasma Research Institute, Shahid Beheshti University, Evin, Tehran, 1983969411, Iran; Tel: +98-21-29904008; Fax: +98-21-22431775; E-mail: a_rastkar@sbu.ac.ir
}

scale, the contact surface of the particles with bacteria increases and results in the higher antibacterial effect of $\mathrm{Cu}$ species.

Nitriding technology is widely used to improve the surface hardness and wear resistance of various steel materials, such as low alloy steels, tool steels and stainless steels. Austenitic stainless steels as a main group of these materials have been extensively surface treated by thermo-chemical diffusion treatments such as nitriding and carburizing processes [3-5]. However, nitriding at low temperatures can be carried out using liquid, gas or plasma environments; the industry is being more interested in plasma nitriding over traditional gas and bath nitriding [6-9]. This is due to many advantages such as reduced gas and energy consumption and the complete removal of environmental hazards. Plasma nitriding at temperatures around $500{ }^{\circ} \mathrm{C}$ can produce thick nitride compound layers on austenitic stainless steels [3-8]. These processes significantly improve the surface hardness and wear resistance of the material. Some recent works have added $\mathrm{Cu}$ as an antibacterial agent in plasma nitrided layers 
which has diminished the hardness or wear resistance of the nitrided layer [6].

Silicon nitride coatings have been extensively investigated to fabricate integrated circuits. In open literature, however, silicon containing compounds such as silicon nitride $\left(\alpha-\mathrm{Si}_{3} \mathrm{~N}_{4}\right)$ coatings have a potential for industrial applications due to their attractive properties such as high temperature solid lubricating, high hardness and strength and high wearresistance [10-14]. Therefore it could be interesting to use this material on the top surface of nitrided surfaces as load bearing material. Silicon nitride $\left(\alpha-\mathrm{Si}_{3} \mathrm{~N}_{4}\right)$ is usually produced by vapor-solid thermal reaction of ammonia and silicon monoxide via catalyst-assisted pyrolysis of polymeric precursors and plasma enhanced chemical vapor deposition (PECVD) of organosilicon compounds. It has been observed by TEM and XRD that the SiCN layers at high temperature are separated into namely $\alpha-\mathrm{Si}_{3} \mathrm{~N}_{4}, \beta-\mathrm{SiC}$ and amorphous silicon oxide [15]. Although ions are important for deposition under plasma conditions, the quality and properties of deposited coatings depend most importantly on the relative contributions of active species, bias voltage, pressure and surface composition [16-18]. Therefore it would be possible at high electron temperatures of cold plasma deposition processes to produce $\alpha-\mathrm{Si}_{3} \mathrm{~N}_{4}$ from silicon containing organometallic compounds.

To our best knowledge, no attempts have been made to deposit silicon nitrides compounds such as $\mathrm{Si}_{3} \mathrm{~N}_{4}$ on plasma nitrided austenitic stainless steel $316 \mathrm{~L}$ and in association with $\mathrm{Cu}$ deposition. The purpose of this paper is to investigate the combined effect of PECVD of silicon nitride from TEOS: $\mathrm{H}_{2}: \mathrm{N}_{2}$ gas mixture after plasma nitriding in addition to $\mathrm{Cu}$ sputtering during the two processes on the microstructure, tribo-mechanical and antimicrobial response of austenitic stainless steel $316 \mathrm{~L}$.

\section{EXPERIMENTAL METHODS AND MATERIAL}

The material used in this work was austenitic stainless steel $316 \mathrm{~L}$. Cylindrical samples with a diameter of $25 \mathrm{~mm}$ and 5 $\mathrm{mm}$ thickness were cut from bar shape material. All stainless steel $316 \mathrm{~L}$ samples were mechanically ground using sandpaper from 160 to 1500 mesh, cleaned in acetone and alcohol and finally air-dried before being placed in the vacuum chamber. Prior to the plasma nitriding process, the samples were sputter-cleaned in the plasma reactor with a gas mixture composed of $50 \%$ A $50 \% \mathrm{H}_{2}$ for $1 \mathrm{~h}$ to remove the characteristic passive film of stainless steel.

Plasma nitriding and PECVD treatments were performed in a laboratory type apparatus with pulsed D.C. power source working at a frequency of $18 \mathrm{kHz}$ (Figure 1). The working pressure of all treatments was adjusted at 10 mbar and different voltages to maintain the cathode (substrate) temperature (nitriding temperature) up to $500{ }^{\circ} \mathrm{C}$. The PECVD treatment of silicon nitride was carried out using tetraethylorthosilicate (TEOS) as a precursor of silicon which was added to the gas mixtures of nitrogen and hydrogen (Table 1). A cylinder made of copper wire was placed around the samples and connected to the cathode to be sputtered simultaneously. The base of the cylinder of copper wire was parallel to the surface of the samples.

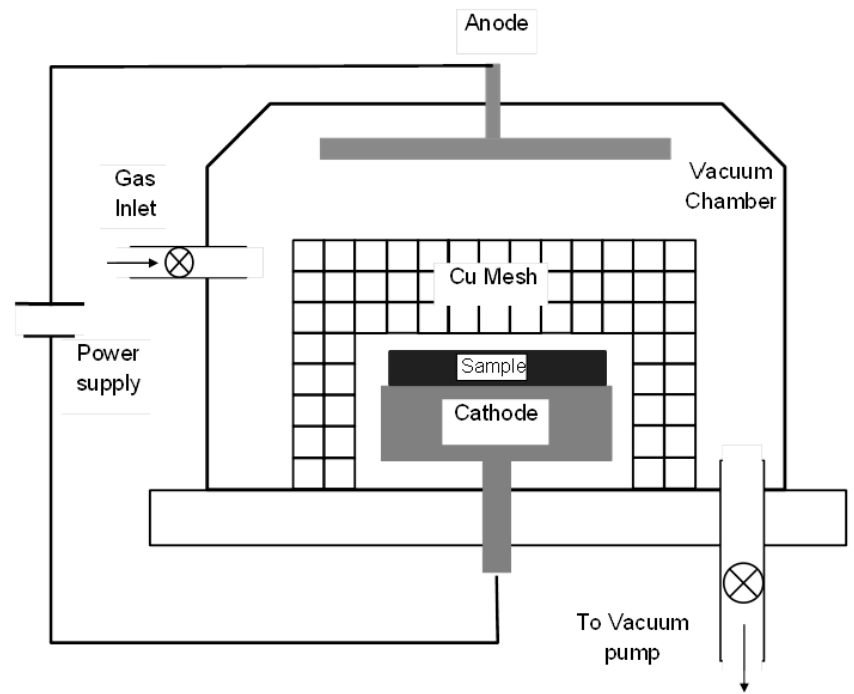

Figure 1: A scheme of the deposition system for $\mathrm{Cu}$ sputtering during plasma nitriding and PECVD treatment.

After treatments, the specimens were allowed to cool in nitrogen atmosphere. X-ray diffraction (XRD) measurements were carried out using $\mathrm{Cu}-\mathrm{Ka}$ radiation $(\lambda=0.154056 \mathrm{~nm})$ with $2 \theta$ scan steps of $0.02^{\circ}$, ranging from $10^{\circ}$ to $90^{\circ}$. Optical microscopy (OM), Electron microscopy and energy dispersive X-ray spectrometry (EDX) were used to analyze the compound layers. The microhardness measurements were

Table 1: The Experimental Conditions of Typical Samples Treated by Cu Deposition during Plasma Nitriding and PECVD Treatment of Stainless Steel 316

\begin{tabular}{|c|c|c|}
\hline Sample & $\begin{array}{c}\text { Plasma Nitriding at } 500{ }^{\circ} \mathrm{C} \text { in } \mathrm{H}_{2}: \mathrm{N}_{2}=1: 3 \text { Gas } \\
\text { Mixture Plus Cu Sputtering for Differnt Times } \\
{[\mathrm{h}]}\end{array}$ & $\begin{array}{c}\text { Subsequent PECVD } \alpha-\mathrm{Si}_{3} \mathrm{~N}_{4} \text { at } 400{ }^{\circ} \mathrm{C} \text { by Addition of } 10 \text { sccm TEOS in } \mathrm{H}_{2}: \mathrm{N}_{2} \\
\text { Gas Mixture after Plasma Nitriding Plus Cu Sputtering for Different Times } \\
\text { [h] }\end{array}$ \\
\hline \hline $\mathrm{S} 1$ & 3 & 0 \\
\hline $\mathrm{S} 2$ & 3 & 1 \\
\hline $\mathrm{S} 3$ & 5 & 0 \\
\hline $\mathrm{S} 4$ & 5 & 1 \\
\hline
\end{tabular}


carried out using a Vickers microhardness tester at $100 \mathrm{~g}$ load.

The friction coefficient and wear rates were evaluated by means of the pin-on-disk tests in dry air at room temperature without lubrication. A normal load of $10 \mathrm{~N}$ was applied to the pin of chromium steel 52100 as the counterpart material at a sliding speed of $10 \mathrm{~mm} / \mathrm{s}$. The friction coefficient $(\mu)$ was recorded during the test and the wear rate $(\mathrm{K})$ was measured after $300 \mathrm{~m}$ using the formula $\mathrm{K}=\mathrm{V} /(\mathrm{F} \times \mathrm{S})$, where $\mathrm{V}$ is the worn volume, $F$ is the normal load, and $S$ is the sliding distance. To measure the worn volume, the depth and width of the wear tracks were determined using a surface profilometer (DEKTAK 8000) and then the cross section area of the tracks multiplied by their diameter. Tests were interrupted at regular intervals of sliding distances in order to monitor the worn volume.
The antibacterial activity of treated layers on SS 316L was tested using a standard spread plate method based on the Japanese JIS Z 2801:2000. Gram-negative Escherichia coli strain NCTC 10418 was selected as test bacteria. The bacteria were cultured in Tryptone soya agar overnight and then diluted in Tryptone soya broth to an optical density OD600 nm of 0.05 , which is equivalent to $10^{7}$ cells $\mathrm{ml}^{-1}$. The samples were sterilized by autoclaving, and then placed on sterile $90 \mathrm{~mm}$ diameter Petri dishes. $300 \mu \mathrm{l}$ of diluted bacterial suspension was pipetted onto each sample. At a relative humidity of higher than $70 \%$ and a temperature of 37 ${ }^{\circ} \mathrm{C}$, the bacteria on the sample surface were incubated. In the specified times the amount of $50 \mu \mathrm{l}$ was transferred to $10 \mathrm{ml}$ of sterile phosphate-buffered saline (PBS) in a sterile container. $100 \mu \mathrm{l}$ of dilution pipetted onto Tryptone soya agar plates. These plates were incubated overnight at $37^{\circ} \mathrm{C}$. The

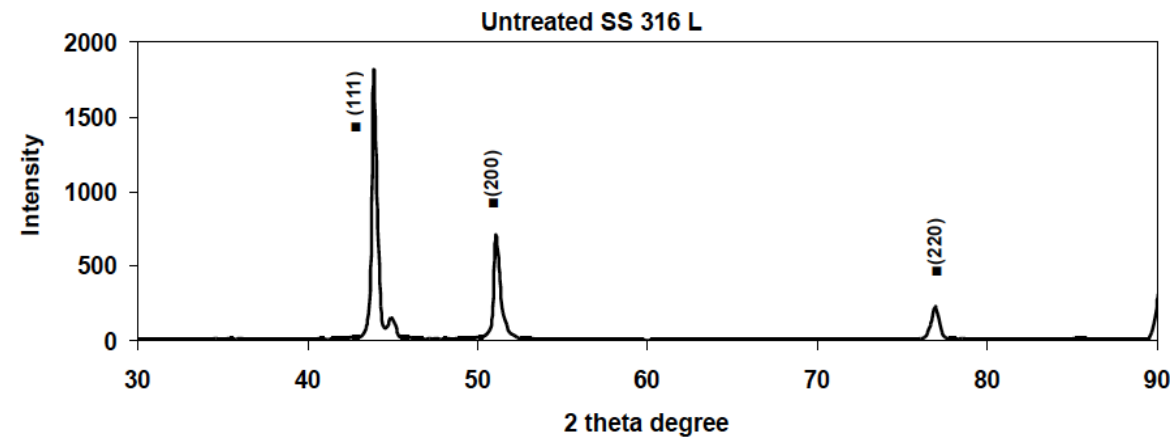

(a)

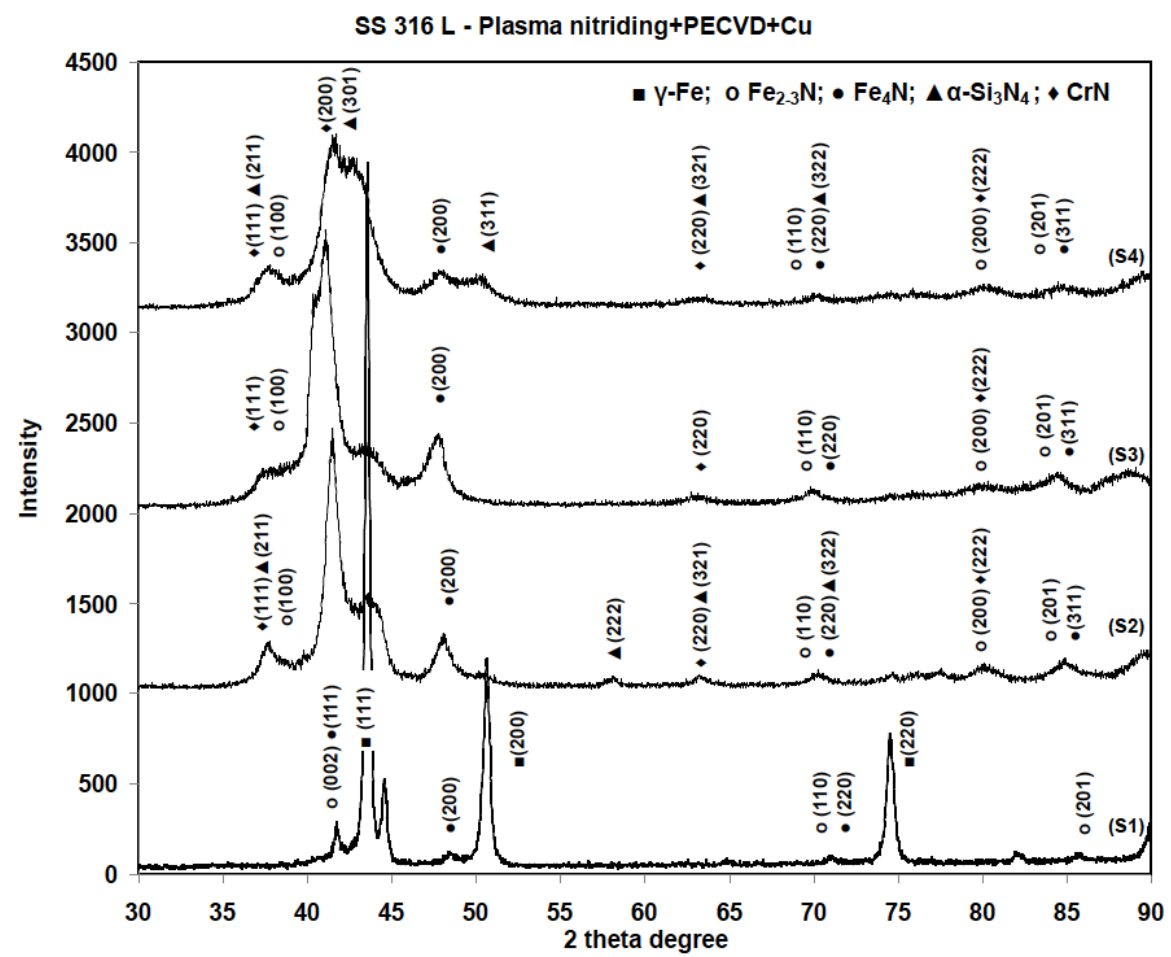

(b)

Figure 2: XRD pattern of (a) untreated stainless steel $316 \mathrm{~L}(\mathbf{b})$ and the samples surface treated by sputtering of $\mathrm{Cu}$ during plasma nitriding at $500{ }^{\circ} \mathrm{C}$ in $\mathrm{H}_{2}: \mathrm{N}_{2}=1: 3$ gas mixture and subsequent PECVD of silicon nitride at $400{ }^{\circ} \mathrm{C}$ for $1 \mathrm{~h}$ by the addition of 10 sccm tetraethylorthosilicate (TEOS) to the gas mixture for different times. 
bacteria colonies that removed from the surface of untreated samples were the control of the experiments. The colony forming units (CFU) resulting from the growth of viable bacterial at $37{ }^{\circ} \mathrm{C}$ after $12 \mathrm{~h}$ enumerated. The percentage reduction was calculated according to the formula: R\% (CFU $\left.\mathrm{ml}^{-1}\right)=\left[\left(\alpha_{\mathrm{t}}-\alpha_{0}\right) / \alpha_{0}\right] \times 100 \%$, where $\mathrm{R} \%$ is the percent of reduction, $\alpha_{\mathrm{t}}$ and $\alpha_{0}$ are the mean CFU ml ${ }^{-1}$ for the treated samples at time $t$ and $0 \mathrm{~min}$.

\section{RESULTS AND DISCUSSION}

\subsection{Phase Identification}

The XRD patterns of some typical treatments are shown in Figure 2. Plasma nitriding of all samples was performed at $500{ }^{\circ} \mathrm{C}$ and resulted in the formation $\mathrm{Fe}_{2-3} \mathrm{~N}$ and $\mathrm{Fe}_{4} \mathrm{~N}$ and $\mathrm{CrN}$ compounds on the surface. These results can be explained by the diffusion mechanisms of nitrogen and chromium. However at $500{ }^{\circ} \mathrm{C}$, the nitrides like $\mathrm{Fe}_{2-3} \mathrm{~N} \mathrm{Fe}_{4} \mathrm{~N}$ and $\mathrm{CrN}$ are formed due to partial decomposition of the metastable supersaturated austenite phase [19]. The XRD pattern of untreated SS 316 in Figure 2a shows the main peaks of $Y(111,200,220)$. The XRD pattern in Figure $\mathbf{2} \mathbf{b}$ for $3 \mathrm{~h}$ plasma nitriding treatment (S1) contains mainly $\mathrm{Y}$-austenite peaks $(111,200,220)$ and distinguishable peaks of $\mathrm{Fe}_{2-3} \mathrm{~N}(002)$ and $\mathrm{Fe}_{4} \mathrm{~N}$ (111). This was due to the passage of $\mathrm{X}$-ray through the thin surface layers and detecting the $\mathrm{Y}$-austenite phase rather than the nitride phases. By increasing the treatment time to $5 \mathrm{~h}$, the peaks of $\mathrm{Fe}_{2-3} \mathrm{~N}$ $(100,002,110), \mathrm{Fe}_{4} \mathrm{~N}(111,200,220)$ and $\mathrm{CrN}(111,220$, 222) appeared clearly in the patterns of S2, S3 and S4 samples. These are attributed to the increased thickness of nitride phases on the surface. It has been shown that $\mathrm{CrN}$ precipitates can be seen under plasma nitriding conditions at temperatures above $460{ }^{\circ} \mathrm{C}$ with gas mixtures containing more than $10 \% \mathrm{~N}_{2}$ gas. Otherwise, the S-phase (expanded austenite, $\mathrm{YN}_{\mathrm{N}}$ ) is observed in the microstructure [20]. The Sphase peaks disappear at temperatures higher than $460{ }^{\circ} \mathrm{C}$. In fact at higher temperatures the solubility of nitrogen in the austenitic structure is exceeded, the metastable S-phase decomposes and the precipitation of $\mathrm{CrN}$ occurs [21]. In both cases, it has been observed that the surface composition is stabilized after approximately $3 \mathrm{~h}$ of nitriding [22].

All XRD analyses were carried out using a standard and calibrated machine with certain precision. Nevertheless no peaks of $\mathrm{Cu}$ element were observed in the XRD patterns. This is mainly attributed to the diffusion and substitution of $\mathrm{Cu}$ element in the iron nitrides lattices. The solubility of $\mathrm{Cu}$ in $\mathrm{Fe}$ lattice is very low. According to the phase diagram of $\mathrm{Fe}-\mathrm{Cu}$, the solid solubility of $\mathrm{Cu}$ in $\mathrm{Fe}$ is about $2.2 \mathrm{w} \%$ at $700{ }^{\circ} \mathrm{C}$ [23]. Therefore at nitriding temperatures, a low amount of $\mathrm{Cu}$ has diffused into the iron nitrides lattices which have not varied the lattice parameters too much. In an antimicrobial investigation by plasma alloying, it has been demonstrated that the diffusion of $\mathrm{Cu}$ into the stainless steel resulted in a unique Cu-containing face-centered cubic (f.c.c.) $\gamma^{\prime}-\mathrm{M}_{4} \mathrm{~N}$
$(\mathrm{M}=\mathrm{Fe}, \mathrm{Cr}, \mathrm{Ni}, \mathrm{Cu})$ layer. Copper existed as substitutional atoms in the $\mathrm{y}^{\prime}-\mathrm{M}_{4} \mathrm{~N}$ (with a concentration of about 5 at \%) and expanded the $Y$ lattice from $4.4 \%$ to $7.5 \%$ [24]. Consequently, it was not expected to observe a significant variation in the position of nitride peaks in the XRD patterns. Moreover no residual stress has been created in the iron nitride lattice due the $\mathrm{Cu}$ occupation and therefore no observable shift was found in the position of nitride peaks.

The peaks of $\alpha-\mathrm{Si}_{3} \mathrm{~N}_{4}(211,321,322)$ phase were detected in the patterns of sample $\mathrm{S} 2$ and the peaks of $\alpha-\mathrm{Si}_{3} \mathrm{~N}_{4}(301$, 311) phase were obviously identified in the pattern of sample S4. These peaks were as strong as $\mathrm{Fe}_{2-3} \mathrm{~N}(100)$ and $\mathrm{Fe}_{4} \mathrm{~N}$ (200). $\alpha-\mathrm{Si}_{3} \mathrm{~N}_{4}$ was the most probable compound on the surface of the two steps treated samples. The structural complexity of silicon nitride is less diverse and mostly $\alpha-\mathrm{Si}_{3} \mathrm{~N}_{4}$ is known at ambient conditions [25]. The stronger existence of $\alpha-\mathrm{Si}_{3} \mathrm{~N}_{4}$ in sample $\mathrm{S} 4$ is assigned to the longer treatment time of this sample. This treatment provided more nitrogen element for combination with $\mathrm{Si}$ element released form the TEOS compound.

XRD analysis after the second step did not show any considerable indication of $\mathrm{Cu}$ in the samples. It may be assigned to the dissolution or very fine structure of $\mathrm{Cu}$ in the surface layers [26-28]. As explained above the diffusion and solubility of $\mathrm{Cu}$ is very low in iron nitride lattices. Therefore it is suggested that any excess $\mathrm{Cu}$ more than its solubility in iron lattice have trapped in vacancies and other defects of nitride layers which have been very fine to be identified by $\mathrm{XRD}$ analysis. It can also be explained from the viewpoint of the direction of XRD analysis. The XRD analyses were carried out from the top surface of the specimens. The penetration depth of $\mathrm{Cu}-\mathrm{Ka}$ radiation into iron alloys is a few microns [29] and the Cu concentration in the top surface layer has been very low. Therefore the counted $\mathrm{Cu}$ has been very low to appear in the XRD patterns. Consequently it was more reliable and possible to detect the $\mathrm{Cu}$ element on the cross section of the samples. Moreover the dispersive energy of the scattered X-ray beams emitted from the particles was enough to be detected by EDX analysis. Consequently it was tried to determine the average $\mathrm{Cu}$ concentrations across the coating layers by EDX line analyses and in some limited area by EDX point analyses. The EDX analyses are shown in the following sections.

\subsection{Microstructural Analysis}

Figure 3a shows the cross section of the sample plasma nitrided for $5 \mathrm{~h}$ and PECVD treated for $1 \mathrm{~h}$ without $\mathrm{Cu}$ deposition, whereas Figure $\mathbf{3 b}$ shows the same sample with $\mathrm{Cu}$ deposition (S4). Several layers can be observed in the compound layers. It is later shown that the dark portions in the top layers belong to $\mathrm{CrN}$ precipitates and $\alpha-\mathrm{Si}_{3} \mathrm{~N}_{4}$ phase. The bright layer underneath the dark layers is most probably composed of $\mathrm{Fe}_{2-3} \mathrm{~N}$ and $\mathrm{Fe}_{4} \mathrm{~N}$ compounds containing $\mathrm{Cu}$ element [30]. 


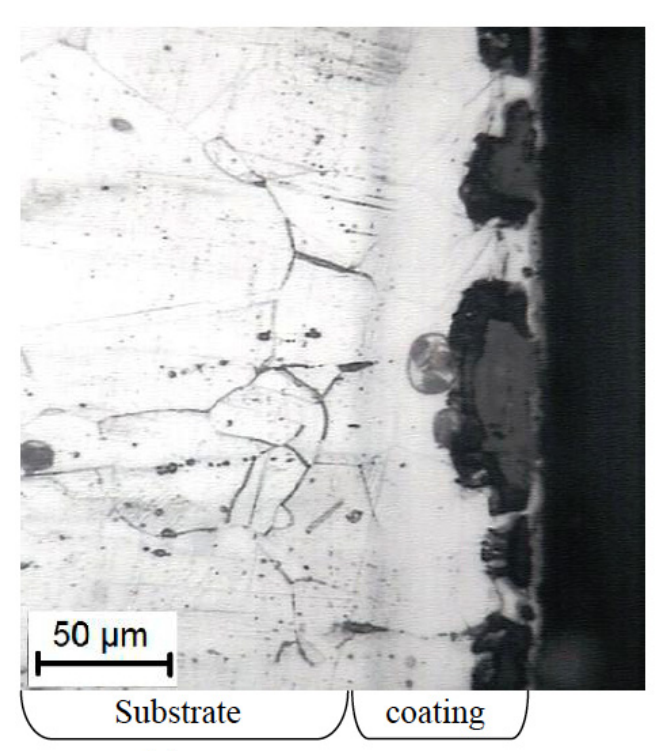

(a)

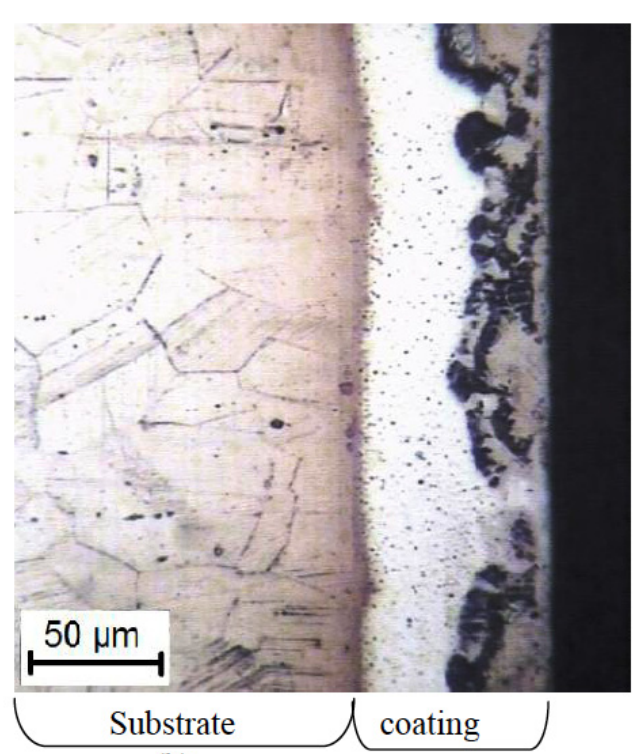

(b)

Figure 3: Optical micrographs of (a) the sample treated by plasma nitriding at $500{ }^{\circ} \mathrm{C}$ in $\mathrm{H}_{2}: \mathrm{N}_{2}=1: 3$ gas mixture for $5 \mathrm{~h}$ and subsequent PECVD of silicon nitride at $400{ }^{\circ} \mathrm{C}$ for $1 \mathrm{~h}$ by the addition of $10 \mathrm{sccm}$ tetraethylorthosilicate (TEOS) to the gas mixture without Cu sputtering deposition and (b) with simultaneous Cu sputtering during the two steps in (a).

In Figure $\mathbf{3 b}$, it is observed that the sample with $\mathrm{Cu}$ deposition (S4) contains some very fine spots in the bright and dark layers. It is believed that these spots belong to the porosities that form during plasma nitriding and PECVD treatment with $\mathrm{Cu}$ deposition. A few amounts of $\mathrm{Cu}$ atoms may diffuse in vacancies and other defects and help the creation of these pores. The concentration of $\mathrm{Cu}$ in these defects or pores has been very low to be detected by XRD. If spots in some places seem larger than nanometric sizes, it is due to the effects of sectioning processes. During polishing the pores were enlarged due to the erosion actions of polishing and etching processes.

The spots are more clearly observed in the SE and BSE modes of the SEM micrographs of sample S3 that only plasma nitrided for $5 \mathrm{~h}$ with $\mathrm{Cu}$ deposition (Figure 4a) and sample S4 that plasma nitrided for $5 \mathrm{~h}$ and PECVD treated for $1 \mathrm{~h}$ with $\mathrm{Cu}$ deposition (Figure 4c). The existence of $\mathrm{Cu}$ was confirmed with EDX line analysis across the surface layers and point EDX analyses (Figure $\mathbf{4 b}$ and $\mathbf{4 d}$ ) in $A$ and $B$ areas shown in SE modes of Figure $\mathbf{4 a}$ and $\mathbf{4 c}$. The EDX analyses were performed according to the standard procedures with standard and calibrated machines. If there has been any nanoparticle of $\mathrm{Cu}$ in the pores, they have been removed and only substitutional $\mathrm{Cu}$ element has been detected by EDX analysis. It can be said that the concentration of $\mathrm{Cu}$ across the layers varied from 1 to $3 \mathrm{w} \%$. Generally in line scan EDX analyses it is seen that the variation of $\mathrm{Cu}$ concentration has diminished in the length analysis of 45 to $55 \mu \mathrm{m}$ in Figure $4 \mathrm{c}$ for sample S3 and 35 to $55 \mu \mathrm{m}$ in Figure $\mathbf{4 d}$ for sample $\mathrm{S} 4$. In these two line scans, the concentration of chromium has increased considerably and the concentration of $\mathrm{Cu}$ has decreased to very low amounts. It can be proposed that $\mathrm{Cr}$ has diffused and accumulated in the top surface layer and prevented $\mathrm{Cu}$ to diffuse more into the interlayer or occupied the $\mathrm{Cu}$ places. Moreover the overall concentration of $\mathrm{Cu}$ in sample $\mathrm{S} 3$ is lower than that of sample S4. This is strongly related to the less diffusion of $\mathrm{Cu}$ in $\mathrm{S} 3$ due to the shorter treatment time. Point EDX analysis of Sample S3 (Figure 4b) did not show any $\mathrm{Cu}$ in $\mathrm{A} 3$ area but a small amount of $\mathrm{Cu}$ in $\mathrm{B} 3$ area. While the point analyses of sample S4 (Figure 4d) revealed a slightly higher and clear signal of $\mathrm{Cu}$ in $\mathrm{A} 4$ and $\mathrm{B} 4$ areas. However the $\mathrm{Cu}$ concentration in $\mathrm{B} 4$ is slightly lower than that in A4 which confirm the relevant line EDX analysis. These observations confirmed the less amount of $\mathrm{Cu}$ in sample $\mathrm{S} 3$ than that in sample S4. From point EDX analyses (Figure $\mathbf{4 b}$ and $\mathbf{4 d}$ ), it can be seen that the relative amount of chromium to iron in B3 area (Figure 4a) is less than that in B4 area (Figure 4c). This difference was observed in line scan analyses (Figure $\mathbf{4 b}$ and $\mathbf{4 d}$ ) which confirm the lower amount of $\mathrm{CrN}$ in the top layers of sample S3 than that in sample S4. However these point analyses confirm the existence and distribution of $\mathrm{Cu}$ across the surface layers varying from 1 to $3 \mathrm{w} \%$.

Maximum content of $\mathrm{Si}$ element appeared near the top surface of the samples (sample S4 in Figure 4d). Si element had a value all along the cross section of the sample and did not decrease to zero in any place if compared to the value of $\mathrm{Cu}$ element. It is suggested that the time of subsequent PECVD of TEOS: H2:N2 treatment has not been long enough to allow the diffusion of more silicon into the underneath layers. The observation of silicon confirmed the existence of $\alpha-\mathrm{Si}_{3} \mathrm{~N}_{4}$ compound.

From Figure 3b and EDX line analysis of sample S4 (Figure 4d), it may be suggested that the top surface layer of the samples that deposited by $\mathrm{Cu}$ during plasma nitriding for $5 \mathrm{~h}$ 


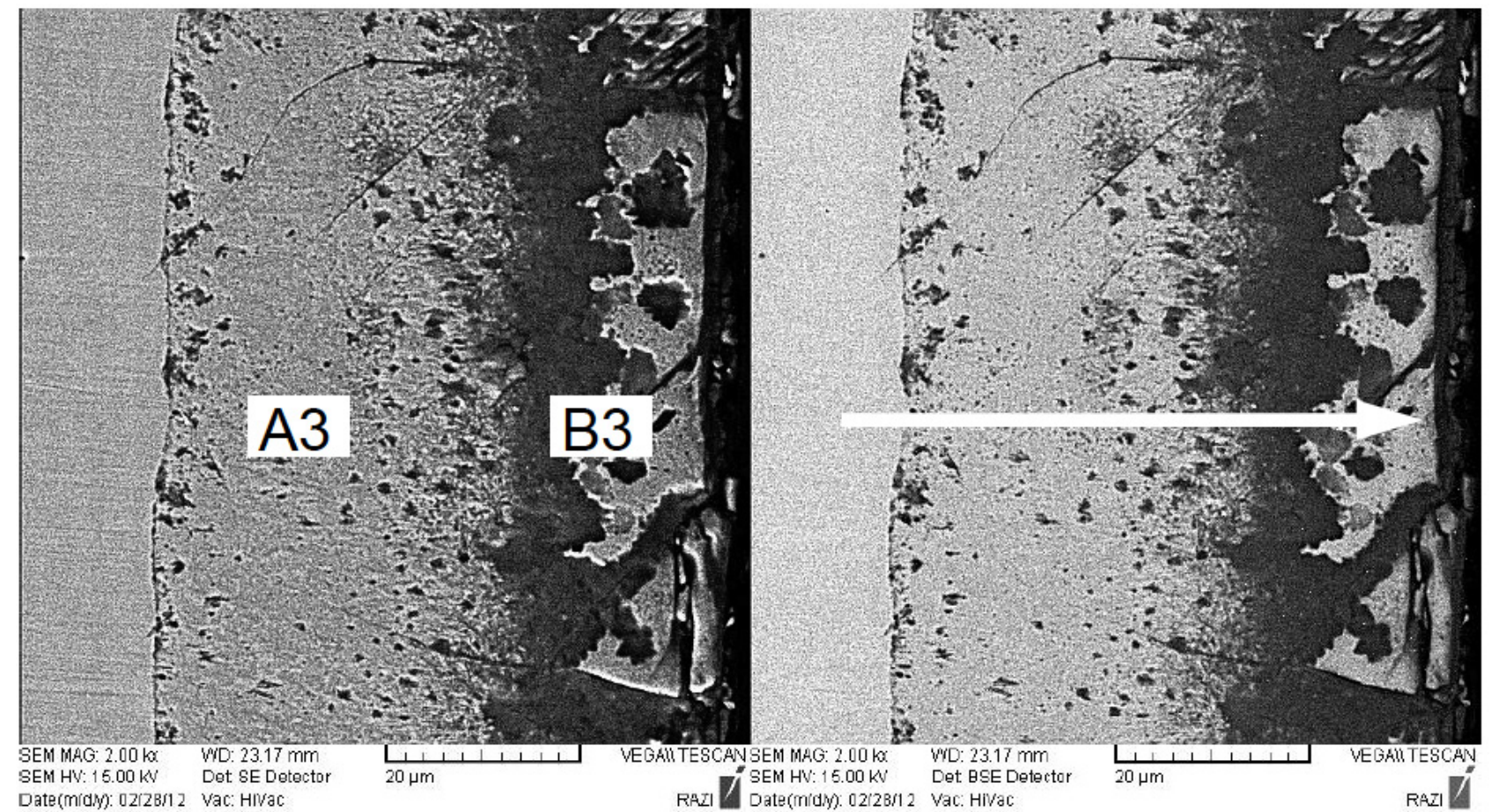

(a)
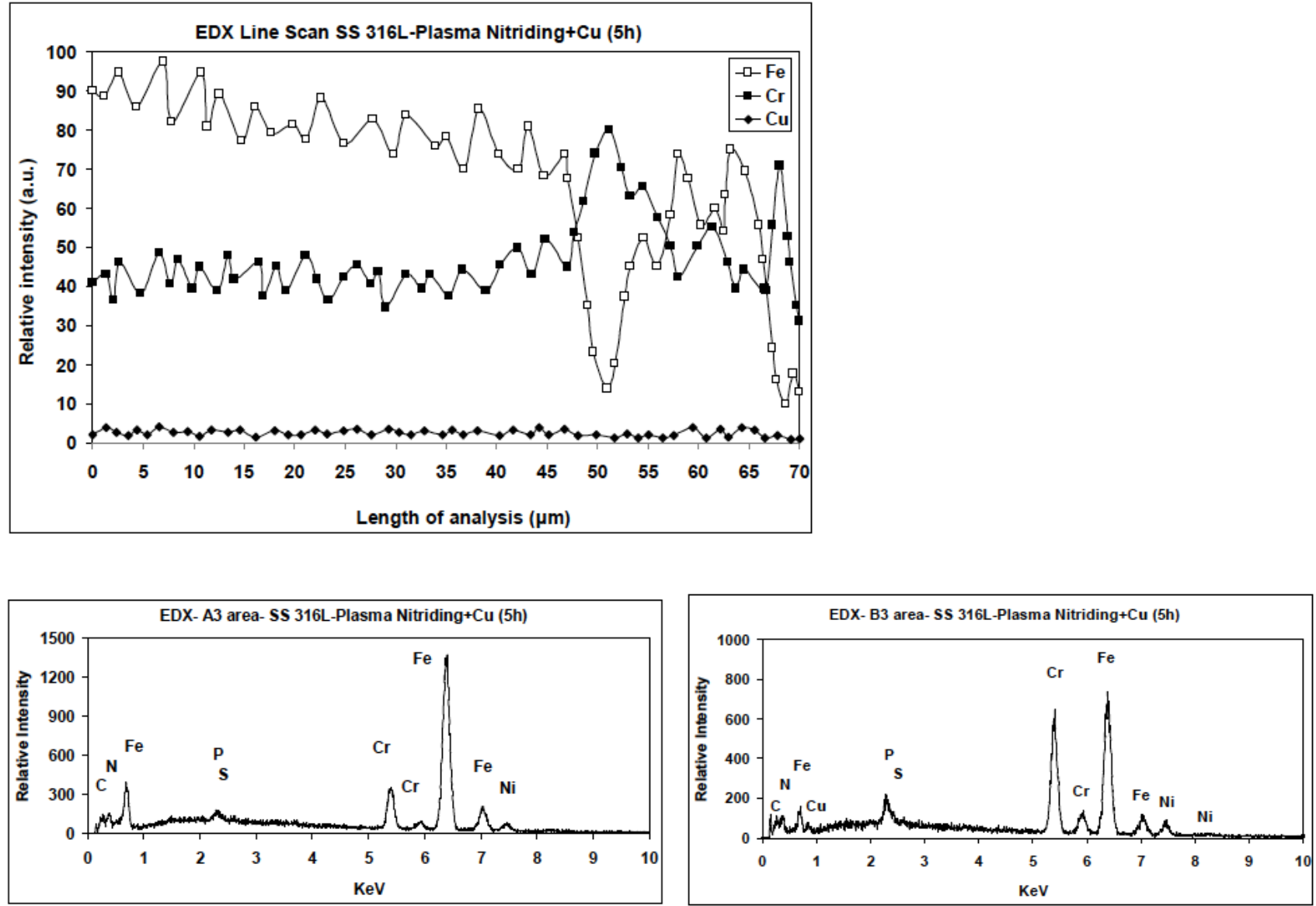

(b) 
(Figure 4). Continued.

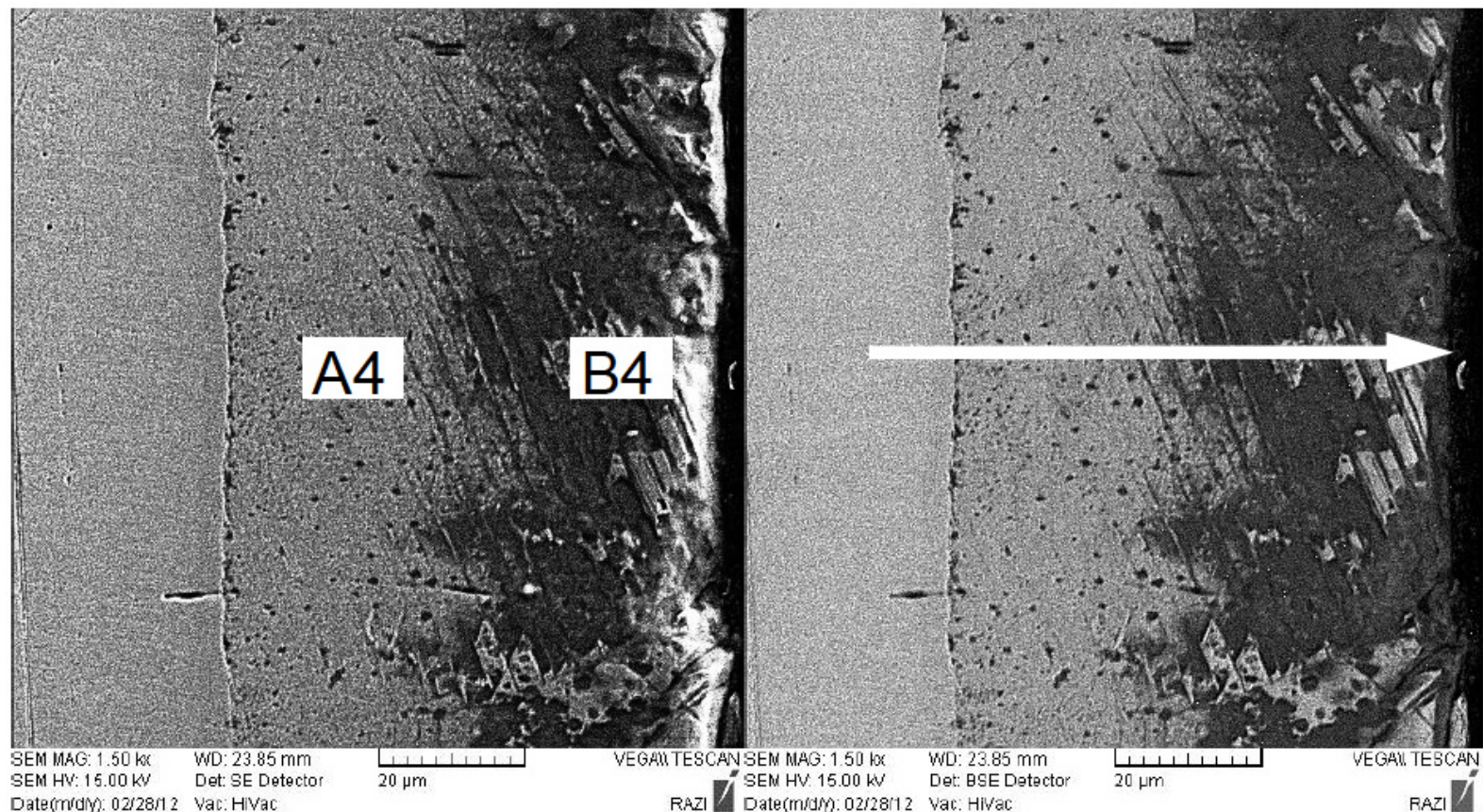

(c)
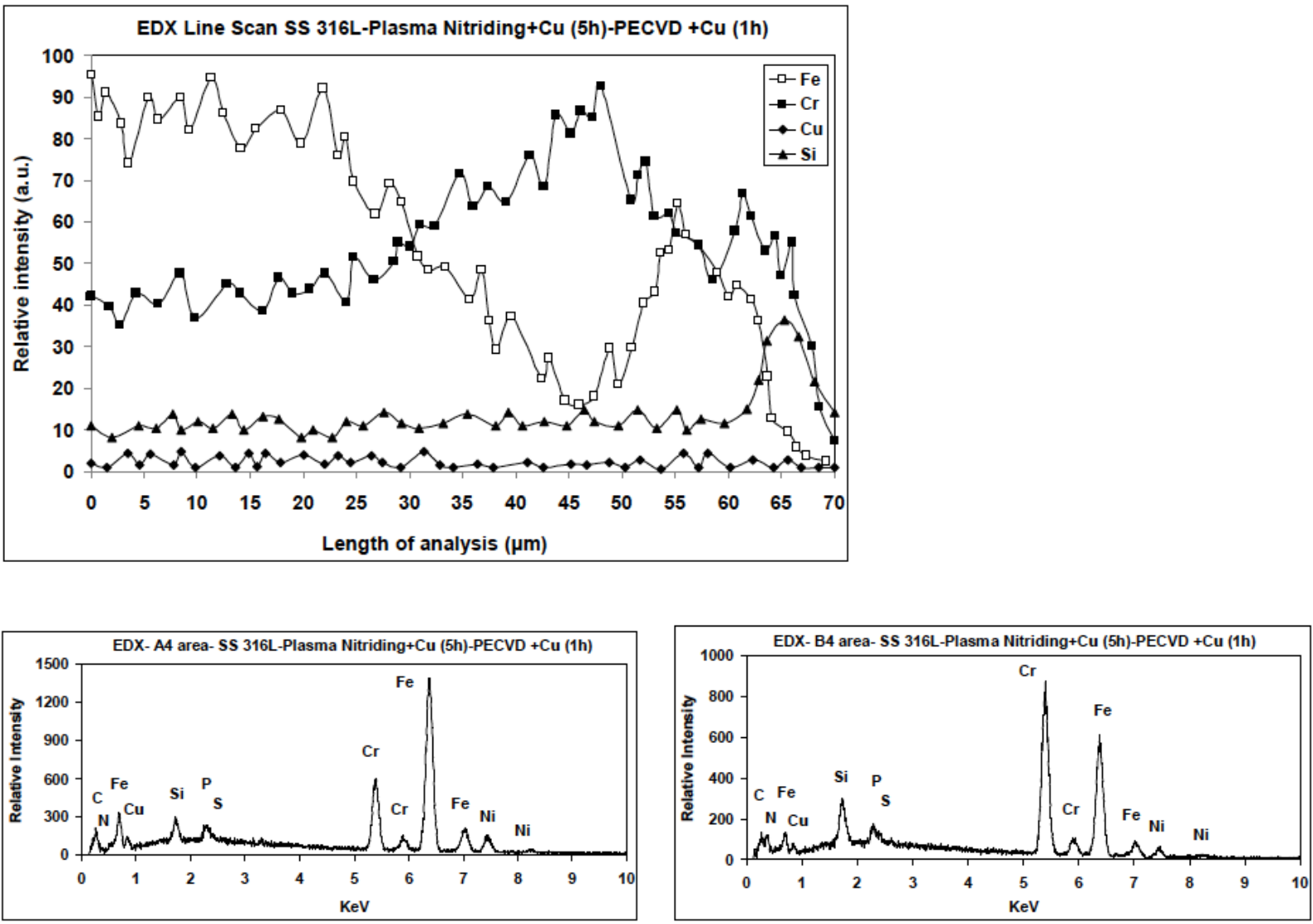

(d)

Figure 4: (a) SE and BSE micrographs of the sample treated by sputtering of Cu during plasma nitriding at $500{ }^{\circ} \mathrm{C}$ in $\mathrm{H}_{2}: \mathrm{N}_{2}=1: 3$ gas mixture for 5 h, (b) EDX line scan along the arrow shown in (a) and point scans of the compound layer in A3 and B3 areas, (c) SE and BSE micrographs of the sample treated by sputtering of $\mathrm{Cu}$ during plasma nitriding at $500{ }^{\circ} \mathrm{C}$ in $\mathrm{H}_{2}: \mathrm{N}_{2}=1: 3$ gas mixture for $5 \mathrm{~h}$ and subsequent PECVD of silicon nitride at $400{ }^{\circ} \mathrm{C}$ for $1 \mathrm{~h}$ by the addition of $10 \mathrm{sccm}$ tetraethylorthosilicate (TEOS) to the gas mixture and (d) EDX line scan along the arrow shown in (c) and point scans of the compound layer in A4 and B4 areas. 


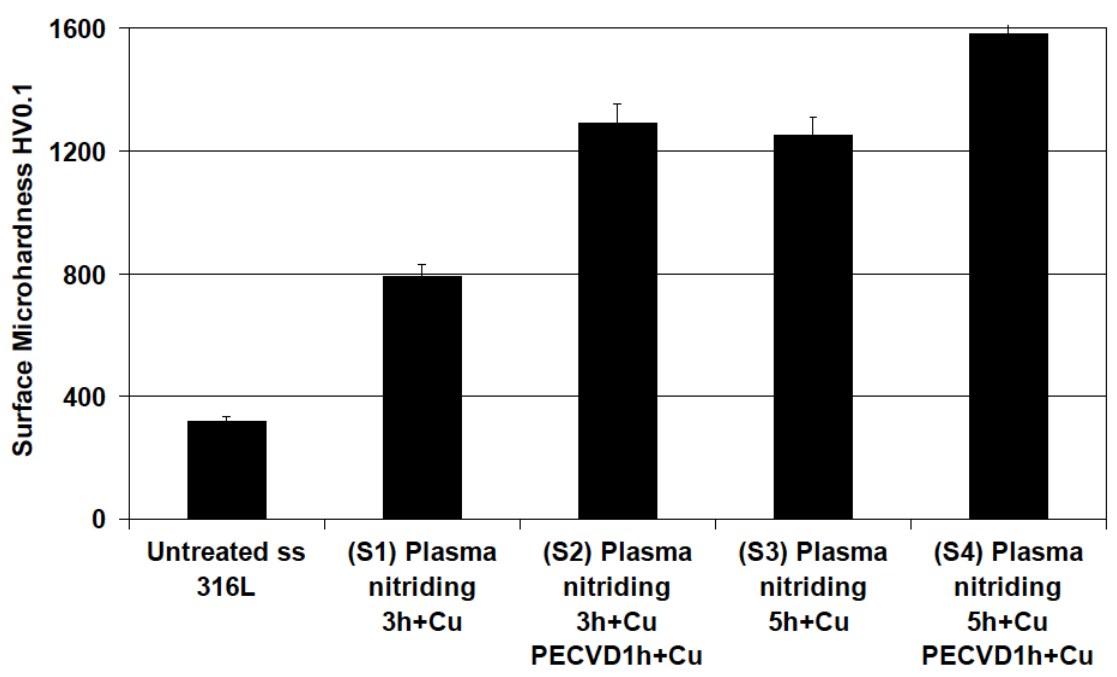

Figure 5: Surface microhardness of untreated stainless steel $316 \mathrm{~L}$ and the samples treated by sputtering of Cu during plasma nitriding at 500 ${ }^{\circ} \mathrm{C}$ in $\mathrm{H} 2: \mathrm{N} 2=1: 3$ gas mixture for different times and subsequent PECVD of silicon nitride at $400{ }^{\circ} \mathrm{C}$ for $1 \mathrm{~h}$ by the addition of 10 sccm tetraethylorthosilicate (TEOS) to the gas mixture.

and PECVD treatment for $1 \mathrm{~h}$ is a mixture of fine grained $\mathrm{CrN}$ and $\alpha-\mathrm{Si}_{3} \mathrm{~N}_{4}$ compounds accompanying a small amount of $\mathrm{Cu}$. From these observations it can also be suggested that the thickness of $\alpha-\mathrm{Si}_{3} \mathrm{~N}_{4}$ was approximately less than $20 \mu \mathrm{m}$.

\subsection{Microhardness Evaluations}

Figure 5 shows the surface microhardness value, measured at an applied load of $100 \mathrm{gf}$, for all selected samples. The surface microhardness value of all treated samples was several times more than that of untreated substrate (320 HV0.1). The higher surface microhardness of the two steps treated layers is attributed to the hardness of hard nitride phases of $\mathrm{Fe}_{2-3} \mathrm{~N}, \mathrm{Fe}_{4} \mathrm{~N}$ and $\mathrm{CrN}$ in association with silicon nitride $\left(\alpha-\mathrm{Si}_{3} \mathrm{~N}_{4}\right)$. It has also been found that the surface hardness of similarly oriented two steps treated samples is improved with respect to the hardness of underlying nitride layers [13]. The surface hardness of the two steps treated samples significantly increased to a maximum value of 2300 HV0.1 with increasing the time of PECVD of TEOS until 1.5 h. At longer treatment times, the hardness decreased gradually with increasing the time. The addition of $\mathrm{Cu}$ during plasma nitriding and $1 \mathrm{~h}$ PECVD of TEOS limited the maximum hardness to 1600 HV0.1. It is believed that this reduction in hardness must be due to the softening effect of copper in the surface layers.

The hardness values of nitrided and PECVD treated samples are a combination of the hardness of the surface layers and the substrate due to the extra depth of indention. It is widely accepted that the hardness of a coating measured by indentations is reliable with penetration depths not exceeding $5-10 \%$ of the total coating thickness, where substrate effects are negligible. A real hardness value of the surface layer should be examined with an indentation depth not exceeding one tenth of the surface layers. In this study, it was not possible to obtain precise indentation impression with loads less than $100 \mathrm{gf}$ due to the distorted small size of the impressions. The real hardness values of the surfaces similarly nitrided and deposited by hard phases have been evaluated by nanoindentation. It has been found that after $3 \mathrm{~h}$ of nitriding, the hardness value exhibited a maximum value of $14 \mathrm{GPa}$ for indentation depths between approximately 50 and $125 \mathrm{~nm}$ in $2 \mu \mathrm{m}$ thickness and for indentation depths higher than $125 \mathrm{~nm}$, the measurements were influenced by the stainless steel bulk [23, 31]. Therefore it may be assumed that the real surface hardness value of treated samples is higher than those measured at $100 \mathrm{gf}$ load. Microhardness measurements at loads less than $100 \mathrm{gf}$ were unreliable and are not reported until nanoindentation measurements are carried out in another study.

\subsection{Friction Behavior and Wear Loss}

PECVD treatment reduced the surface roughness of plasma nitrided surfaces. The decrease in the roughness facilitates the relative motion at the contact surface and in turn improves the friction behavior, such that the smoother surfaces are more suitable for exposure to sliding contact.

Figure 6 compares typically the friction behavior of untreated stainless steel (Figure 6a) and the sample deposited with $\mathrm{Cu}$ during only plasma nitriding (S3 in Figure 6b) and the sample deposited with $\mathrm{Cu}$ during plasma nitriding and pulsed dc PECVD of silicon nitride $\left(\alpha-\mathrm{Si}_{3} \mathrm{~N}_{4}\right)$ compound (S4 in Figure 6c). The friction coefficients of untreated sample increased quickly to 0.3 after a short sliding distance and to 0.5 after $500 \mathrm{~m}$ sliding distance. However the sample S3 approached 0.3 after a sliding distance of $300 \mathrm{~m}$, the friction coefficient of $\alpha-\mathrm{Si}_{3} \mathrm{~N}_{4}$ layers on PECVD treated sample (S4) was in the range of 0.1 for more than $300 \mathrm{~m}$ and increased to a value of about 0.3 after a much longer sliding distance of $500 \mathrm{~m}$.

The general decrease in the coefficient of friction of treated samples can be explained by the nature of the surface layers and variation in the surface roughness of the compounds 
formed by plasma nitriding and PECVD treatment. The average surface roughness $(\mathrm{Ra})$ of untreated stainless steel was around $0.45 \mu \mathrm{m}$. The surface roughness increased up to 5 times $(2.3 \mu \mathrm{m})$ using plasma nitriding and decreased to approximately half of that $(1.3 \mu \mathrm{m})$ by PECVD treatment. Sliding wear showed random variations of friction behavior for untreated stainless steel (Figure 6a) and the sample S3 that $\mathrm{Cu}$ deposited during plasma nitriding for $5 \mathrm{~h}$ (Figure 6b). This kind of variation in friction behavior has been observed by many investigations in nitriding processes [3-8]. Nevertheless the surface layers on sample $\mathrm{S} 3$ had a little amount of $\mathrm{Cu}$ element that helped to the reduction of friction coefficient but did not reduce the variations in the value of friction coefficient. Therefore it may be concluded that the substitution of $\mathrm{Cu}$ in the crystal structure of iron nitrides has not had a significant effect on the friction behavior of these alloys and only very fine particles of $\mathrm{Cu}$ have occasionally reduced the friction coefficient slightly.

The friction variation of the PECVD treated sample S4 (Figure 6c) was very low. The friction behavior was very smooth until approximately $300 \mathrm{~m}$ sliding distance and gradually increased with increasing distance. The smooth behavior is partly attributed to the low roughness of PECVD

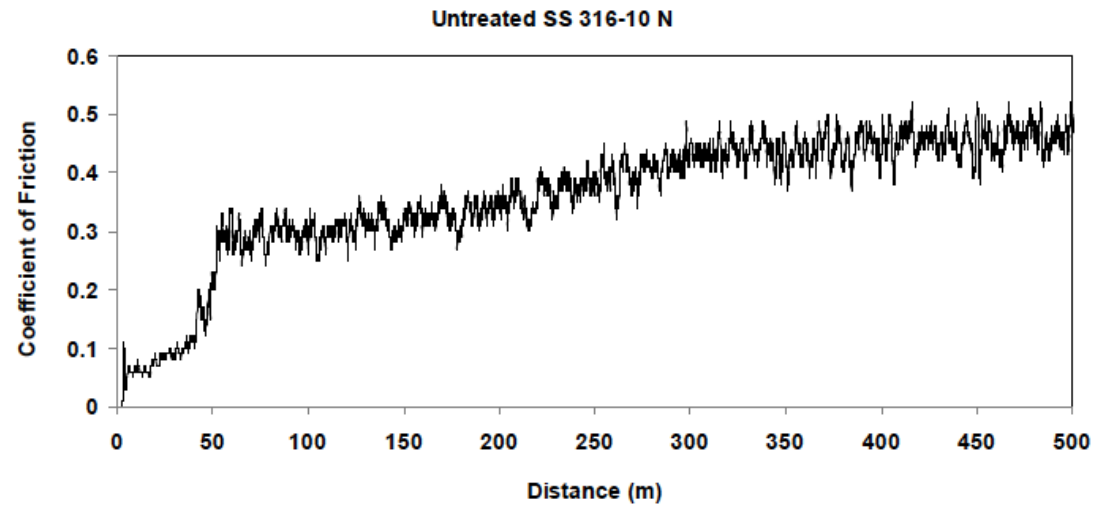

(a)

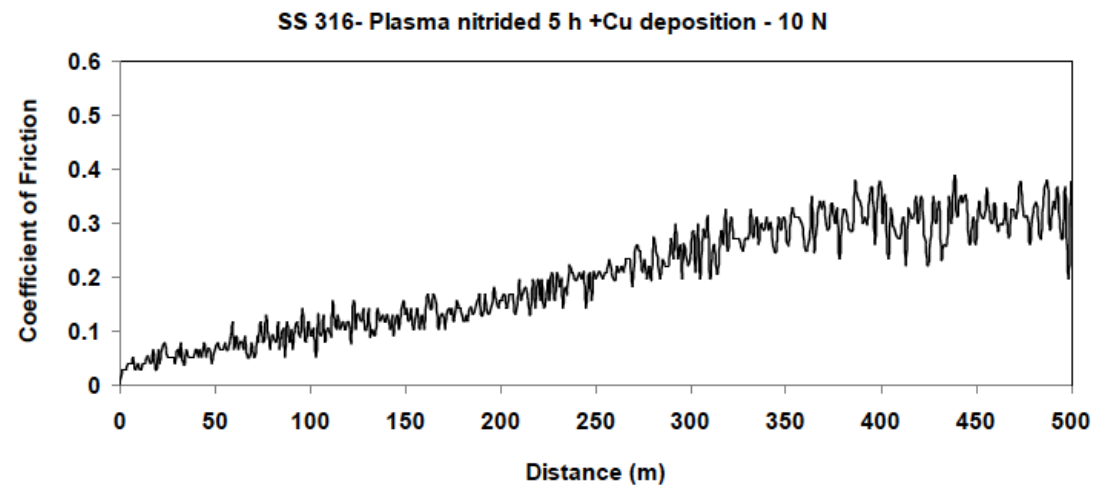

(b)

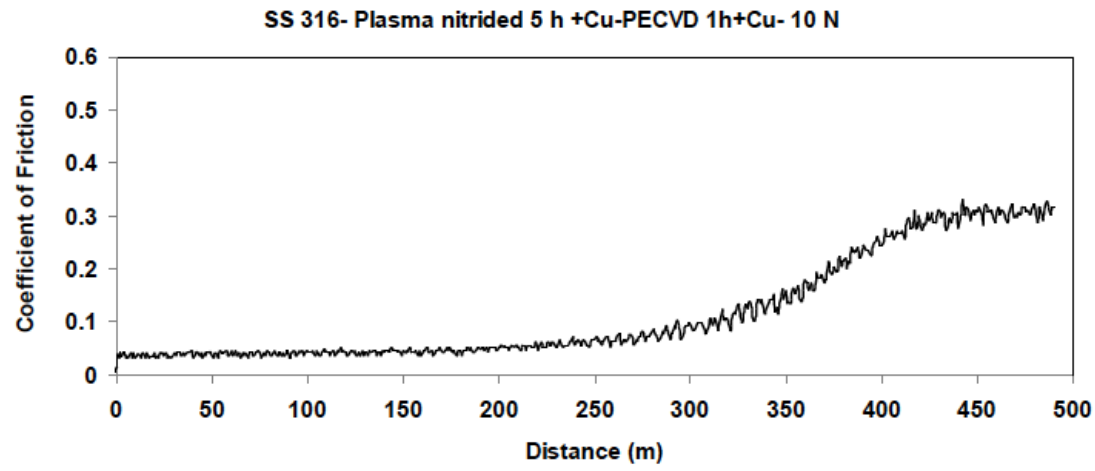

(c)

Figure 6: Friction behavior under $10 \mathrm{~N}$ load of (a) untreated stainless steel $316 \mathrm{~L}$, (b) the sample $\mathrm{S} 3$ treated by Cu sputtering during plasma nitriding at $500{ }^{\circ} \mathrm{C}$ in $\mathrm{H} 2: \mathrm{N} 2=1: 3$ gas mixture for $5 \mathrm{~h}$ and (c) the sample $\mathrm{S} 4$ treated by Cu sputtering during plasma nitriding at $500{ }^{\circ} \mathrm{C}$ in $\mathrm{H} 2$ : N2=1:3 gas mixture for $5 \mathrm{~h}$ and subsequent PECVD of silicon nitride at $400{ }^{\circ} \mathrm{C}$ for $1 \mathrm{~h}$ by the addition of 10 sccm tetraethylorthosilicate (TEOS) to the $\mathrm{H} 2: \mathrm{N} 2=1: 3$ gas mixture. 
treated sample S4 which was approximately one half of the roughness of sample S3. The low friction value until $300 \mathrm{~m}$ is mainly correlated to the low friction of silicon nitride $\left(\alpha-\mathrm{Si}_{3} \mathrm{~N}_{4}\right)$ compound and $\mathrm{Cu}$ particles [10]. It is also believed that $\alpha-$ $\mathrm{Si}_{3} \mathrm{~N}_{4}$ and $\mathrm{Cu}$ on the surface layers have not interacted with the counterpart and consequently the friction coefficient has been very low up to a certain sliding distance.

The increase in the friction value after $300 \mathrm{~m}$ is attributed to the gradual removal of silicon nitride compound layer and consequently exposure to iron nitride phases.

It has been observed that initial roughness, contact pressure, sliding velocity, material combination and environment influence the resulting values of friction coefficient and wear rate. Brittleness, low toughness and high hardness of such ceramics as silicon nitride $\left(\alpha-\mathrm{Si}_{3} \mathrm{~N}_{4}\right)$ limit the junction-growth at asperity contacts and keep friction coefficient very low even when interlocking of asperities take a large part of friction in unlubricated pin on disk sliding in air [32]. It may also be added that the resistance increases by the work hardening effect that always occurs in austenitic stainless steel, even in nitrided or surface treated steel when the treated layer is broken [30].

Dry-sliding wear rate of untreated $316 \mathrm{~L}$ stainless steel and treated samples is shown in Figure 7. It was observed that in all tests after $500 \mathrm{~m}$ sliding distance, the wear rate of untreated stainless steel $316 \mathrm{~L}$ was much higher than that of treated samples. The wear rate of the samples $\mathrm{Cu}$ deposited during plasma nitriding decreased to one third of the wear rate of untreated material after $3 \mathrm{~h}$ treatment (S1) or even less after $5 \mathrm{~h}$ treatment (S3). The wear rate decreased up to one order of magnitude by subsequent PECVD treatment of plasma nitriding (S2 and S4). This was a great improvement in the wear resistance of stainless steel $316 \mathrm{~L}$ in comparison with that of single plasma nitriding processes. This phenomenon is explained mainly by the wear resistance of silicon nitride $\left(\alpha-\mathrm{Si}_{3} \mathrm{~N}_{4}\right)$ compound. However the Cu particles may reduce the interaction of the samples with the counterpart material (52100 steel) that helps the sliding action during the sliding distance. The existence of $\mathrm{Cr}$ nitrides is also mainly responsible for wear resistance or the reduction in wear loss of nitrided layers. However their friction coefficient is high and causes the fluctuations in the friction behavior (Figure 6b).

The observation of wear tracks revealed the wear feature on the worn surfaces (Figure 8). The worn surface of untreated stainless steel was ploughed by counterpart chromium steel (Figure 8a). Also adhesive wear with deep ploughing and deforming scars were observed on the surface (Figure 8b). The width of wear tracks on samples S3 and S4 (Figure 8c and $\mathbf{8 d}$ ) were greater than that of untreated material. However the asperities on the worn surface of samples S3 and S4 were slightly deformed and removed by the counteraction of chromium steel. This feature is characteristic of abrasive wear and occurs on hard and wear resistant surfaces. Nevertheless it is also assigned to the lubricating action of $\mathrm{Cu}$ nanoparticles that resulted in the promotion of the abrasive behavior. The width of the wear track on sample S4 was more than that of sample S3. While the depth of this wear track was shallow. This is correlated to the higher wear resistance of sample S4 which resulted in the flattening of the pin counterpart. The measurement of the depth in the wear tracks confirmed these proposals. The greater depth of wear track in untreated material (nearly $650 \mu \mathrm{m}$ ) showed the much higher wear loss of the substrate than that of treated samples S3 and S4. The depth of the wear track in treated samples S3 and S4 was approximately in average 1.5 and $0.5 \mu \mathrm{m}$ respectively. Moreover the shallower depths in the wear track of sample S4 confirmed the lower wear rate of silicon nitride $\left(\alpha-\mathrm{Si}_{3} \mathrm{~N}_{4}\right)$ which contained $\mathrm{Cu}$ in two step treated samples. In fact the thin silicon nitride layers with $\mathrm{Cu}$ particles resisted most of the wear until they were removed and the

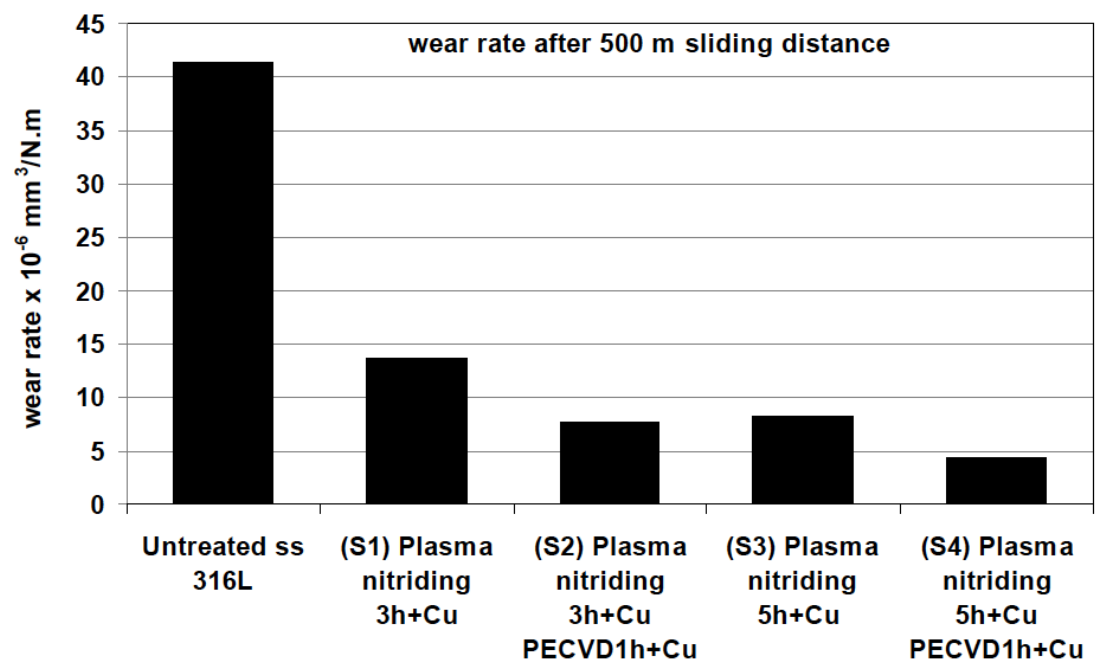

Figure 7: wear rate of untreated stainless steel $316 \mathrm{~L}$ and the samples treated by plasma nitriding at $500{ }^{\circ} \mathrm{C}$ in $\mathrm{H} 2: \mathrm{N} 2=1: 3$ gas mixture for different times and subsequent PECVD of silicon nitride at $400{ }^{\circ} \mathrm{C}$ for $1 \mathrm{~h}$ by the addition of $10 \mathrm{sccm}$ tetraethylorthosilicate (TEOS) to the gas mixture with simultaneous Cu deposition during two steps. 


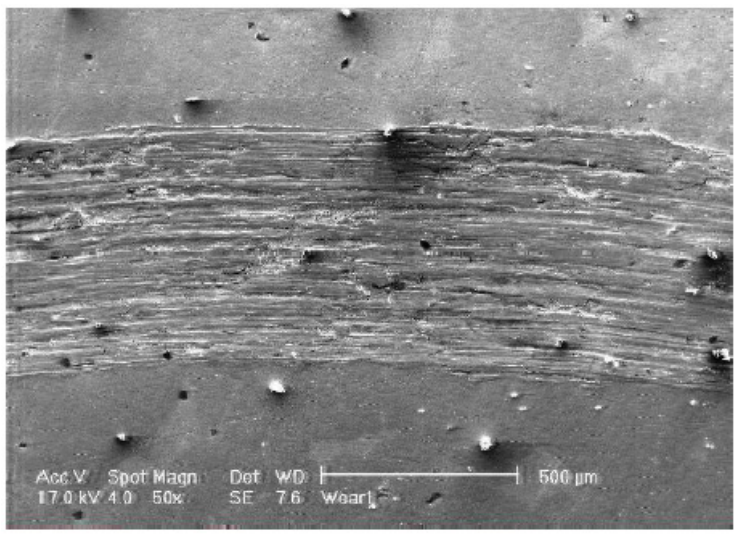

(a)

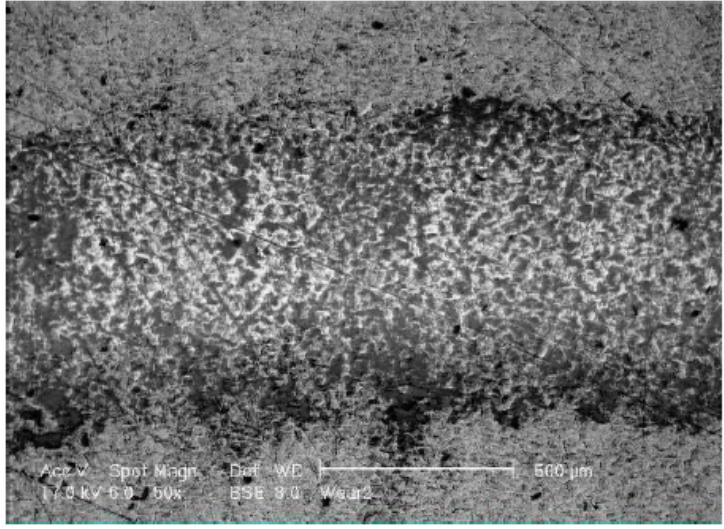

(c)

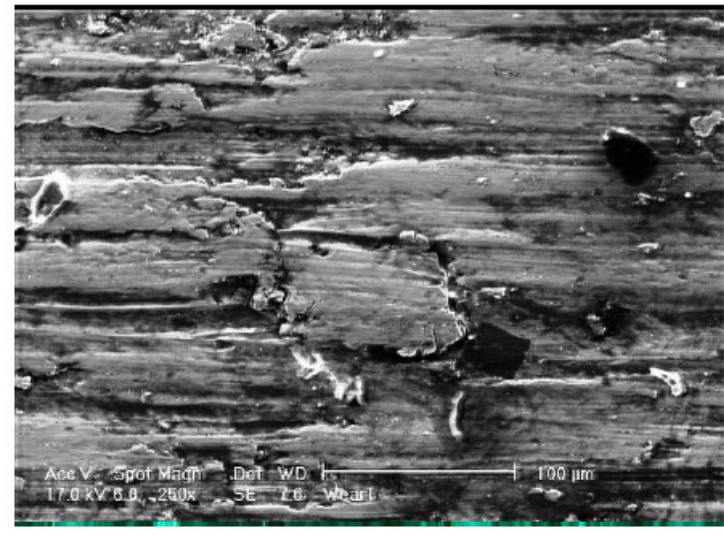

(b)

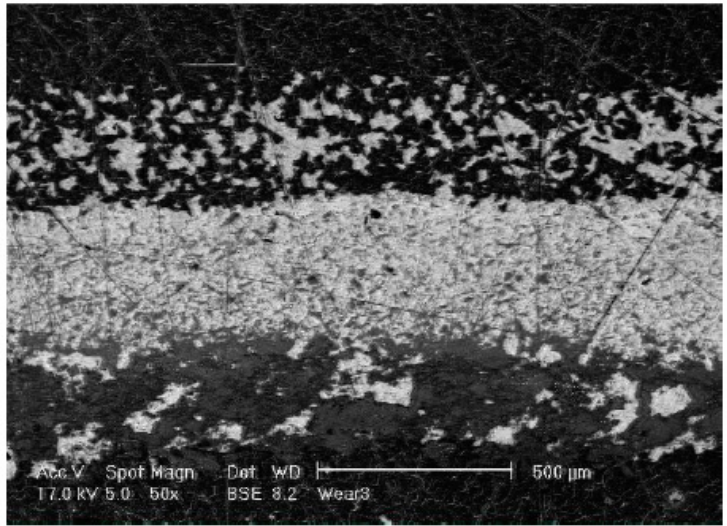

(d)

Figure 8: SEM micrographs show the worn surfaces of (a) untreated stainless steel $316 \mathrm{~L}$, (b) the feature of adhesive wear on untreated sample, (c) the abrasive wear on the sample S3 treated by Cu sputtering during plasma nitriding at $500{ }^{\circ} \mathrm{C}$ in $\mathrm{H} 2: \mathrm{N} 2=1: 3 \mathrm{gas}$ mixture for $5 \mathrm{~h}$ and (d) the wider abrasive wear track on the sample S4 treated by Cu sputtering during plasma nitriding at $500{ }^{\circ} \mathrm{C}$ in $\mathrm{H} 2: \mathrm{N} 2=1: 3 \mathrm{gas}$ mixture for $5 \mathrm{~h}$ and subsequent PECVD of silicon nitride at $400{ }^{\circ} \mathrm{C}$ for $1 \mathrm{~h}$ by the addition of $10 \mathrm{sccm}$ tetraethylorthosilicate (TEOS) to the H2:N2=1:3 gas mixture.

counteracting pin material reached the nitride phases which contained less $\mathrm{Cu}$ element. In spite of the major role of hard phases in wear resistance, it can also be stated that the $\mathrm{Cu}$ element helped to achieve the higher wear resistance and the less wear rate in treated samples.

\subsection{Bacteria Viability on Treated Surfaces}

The percentage reduction of bacteria or killing effect of $\mathrm{Cu}$ in the samples treated by plasma nitriding and subsequent PECVD treatment is shown in Figure 9. The control was untreated stainless steel. It can be seen that the killing effect of the samples that treated only by plasma nitriding ( $\mathrm{S} 1$ and S3) was more than that of samples $S 2$ and $S 4$ treated by the subsequent PECVD of silicon nitride $\left(\alpha-\mathrm{Si}_{3} \mathrm{~N}_{4}\right)$. The bacteria viability on samples S1 and S3 may be 2 to $3 \mathrm{~h}$, while it is nearly 3.5 and $4 \mathrm{~h}$ on the surface of PECVD treated samples S2 and S4. It was suggested that the diffusion of silicon during PECVD treatment has prevented the diffusion of $\mathrm{Cu}$ or occupied the places of $\mathrm{Cu}$ in the nitride lattices. This reaction has reduced the amount $\mathrm{Cu}$ in the top surface layers and consequently reduced the killing effect of copper. However the PECVD deposition of silicon nitride $\left(\alpha-\mathrm{Si}_{3} \mathrm{~N}_{4}\right)$ increased the hardness and wear resistance of plasma nitrided samples, it reduced the killing effect of nitride surfaces which could be a compromise between tribological improvement and killing effect of bacteria.

\section{CONCLUSION}

Copper was sputtered on the samples during plasma nitriding of stainless steel 316L and subsequent plasma enhanced chemical vapor deposition of silicon nitride compounds based on TEOS as a precursor. The composition, phases, hardness and mechanical properties of treated surfaces were systematically investigated. Plasma nitriding at $500{ }^{\circ} \mathrm{C}$ for 3 to $5 \mathrm{~h}$ in $\mathrm{H}_{2}: \mathrm{N}_{2}=1: 3$ gas mixture resulted in the formation of $\mathrm{Fe}_{2-3} \mathrm{~N}, \mathrm{Fe}_{4} \mathrm{~N}$ and $\mathrm{CrN}$ compounds which contained small amounts of substitutional $\mathrm{Cu}$ element. In the XRD patterns, no displacement was observed in the position of $2 \theta$ diffraction angles of iron and chromium nitrides due to the substitution of $\mathrm{Cu}$ element. PECVD of TEOS in $\mathrm{H}_{2}: \mathrm{N}_{2}$ gas mixture after plasma nitriding created $\alpha-\mathrm{Si}_{3} \mathrm{~N}_{4}$ compound on the top surface of nitrided samples. Cu element in $\alpha-\mathrm{Si}_{3} \mathrm{~N}_{4}$ was lower than that in iron and chromium nitrides. Cu was only detected through EDX line analysis across the surface layers. 


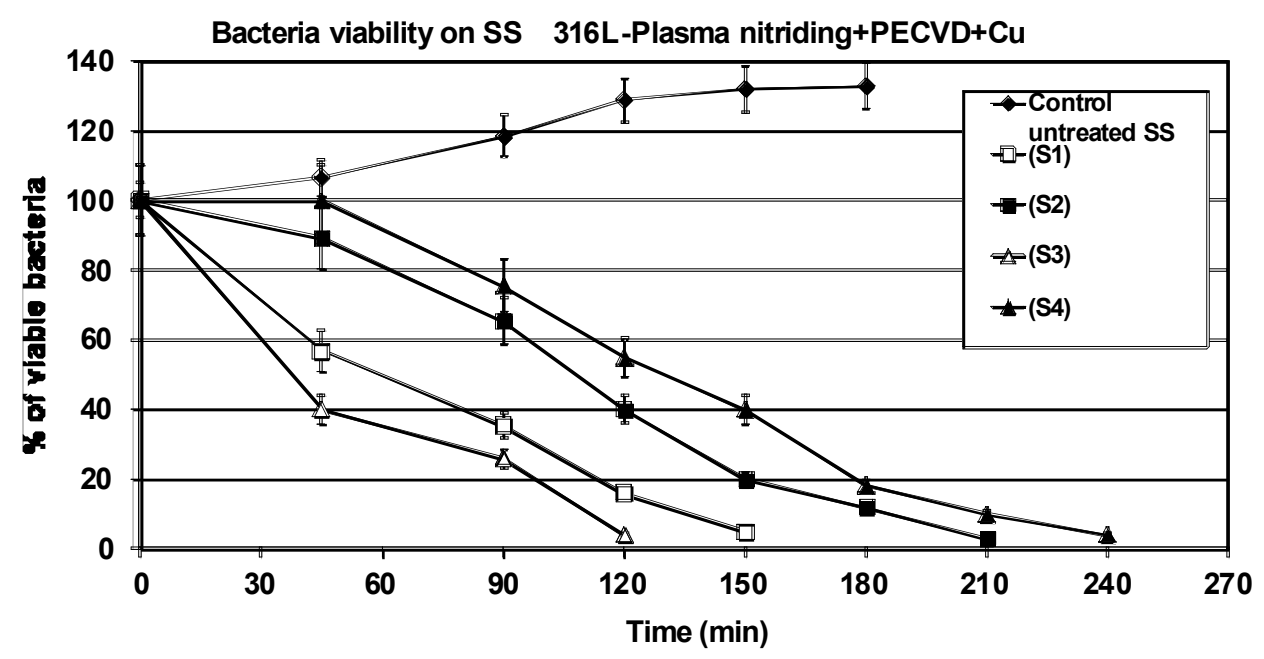

Figure 9: Percentage of viable bacteria vs. contact time on untreated stainless steel $316 \mathrm{~L}$ (control) and the samples surface treated by $\mathrm{Cu}$ sputtering during plasma nitriding at $500{ }^{\circ} \mathrm{C}$ in $\mathrm{H}_{2}: \mathrm{N}_{2}=1: 3$ gas mixture and subsequent PECVD of silicon nitride at $400{ }^{\circ} \mathrm{C}$ for $1 \mathrm{~h}$ by the addition of $10 \mathrm{sccm}$ tetraethylorthosilicate (TEOS) to the gas mixture for different times.

Therefore the detected $\mathrm{Cu}$ belonged to the $\mathrm{Cu}$ diffused or precipitated in the pores of the surface layers. The samples did not have considerable diffusion layers. The surface microhardness reached as high as $1600 \mathrm{HVO} .1$ after $\mathrm{Cu}$ deposition during plasma nitriding at $500{ }^{\circ} \mathrm{C}$ for $5 \mathrm{~h}$ and subsequent PECVD treatment for $1 \mathrm{~h}$. While the highest microhardness on the two steps treated samples without $\mathrm{Cu}$ was as high as $2300 \mathrm{HV} 0.1$. The friction coefficient of treated surfaces reduced considerably. It was nearly 0.1 until $300 \mathrm{~m}$ sliding distance for PECVD treated sample. This was a great improvement in the friction behavior of treated stainless steel $316 \mathrm{~L}$ ever made. The value and variation of friction coefficient of the samples that $\mathrm{Cu}$ deposited during plasma nitriding were higher than those samples that $\mathrm{Cu}$ deposited during both plasma nitriding and PECVD treatment. This was correlated to the low interaction or less adhesive nature of $\alpha-\mathrm{Si}_{3} \mathrm{~N}_{4}$ compound with the counterpart chromium steel in comparison with adhesive nature of iron nitride compounds. However it is believed that $\mathrm{Cu}$ helped to the reduction of friction coefficient and wear loss.

The high hardness or surface strengthening of treaded layers increased the wear resistance of stainless steel $316 \mathrm{~L}$ up to one order of magnitude under pin on disc conditions against SAE 52100 counterface. This was considerably greater than that of single plasma nitriding process. The wear tracks on treated surfaces were shallow and showed abrasive wear damage which is the characteristics of hard and wear resistance surfaces.

The percentage reduction of bacteria or killing effect of $\mathrm{Cu}$ addition during only plasma nitriding was more than that of $\mathrm{Cu}$ addition during two step treated samples and much more than that of untreated stainless steel (control). The bacteria viability was approximately 2 to $3 \mathrm{~h}$ on the samples that only plasma nitrided with $\mathrm{Cu}$ addition. While it was 3.5 to $4 \mathrm{~h}$ on the samples that PECVD treated after plasma nitriding with $\mathrm{Cu}$ addition.

\section{ACKNOWLEDGEMENTS}

The author acknowledges Shahid Beheshti University in the Islamic republic of Iran for the financial support of this study.

\section{REFERENCES}

[1] Fossati A, Borgioli F, Galvanetto E, Bacci T. Glow discharge nitriding of AISI 316L austenitic stainless steel: influence fo treatment time. Surf Coat Technol 2006; 200: 3511-7. http://dx.doi.org/10.1016/..surfcoat.2004.10.122

[2] Lamb S. CASTI Handbook of Stainless Steel and Nickel Alloys. Canada: CASTI Publishing Inc ASM International; 2001.

[3] Li CX, Bell T. Corrosion properties of active screen plasma nitrided 316 austenitic stainless steel. Corr Sci 2004; 46: 1527-47. http://dx.doi.org/10.1016/i.corsci.2003.09.015

[4] Saied C, Chala A, Nouveau C, Djouadi MA, Chekour L. Determination of the Optimum Conditions for lon Nitriding of 32CDV13 Low Alloy Steel. Plasma Process Polym 2007; 4: S757-60. http://dx.doi.org/10.1002/ppap.200731812

[5] Czerwiec T, He H, Marcos G, Thiriet T, Weber S, Michel H. Fundamental and innovations in plasma assisted diffusion of nitrogen and carbon in austenitic stainless steels and related alloys. Plasma Process Polym 2009; 6: 401-9. http://dx.doi.org/10.1002/ppap.200930003

[6] Li CX, Bell T. Corrosion properties of plasma nitrided AISI 410 martensitic stainless steel in $3.5 \% \mathrm{NaCl}$ and $1 \% \mathrm{HCl}$ aqueous solutions. Corr Sci 2006; 48: 2036-49. http://dx.doi.org/10.1016/i.corsci.2005.08.011

[7] Rolinski E. Effect of plasma nitriding temperature on surface properties of austenitic stainless steel. Surf Eng 1987; 3: 35-40. http://dx.doi.org/10.1179/sur.1987.3.1.35

[8] Yasumaru N. Low-temperature ion nitriding of austenitic stainless steels. Mater Trans JIM 1998; 39: 1046-52.

http://dx.doi.org/10.2320/matertrans1989.39.1046

[9] Bell T, Sun Y. Plasma surface engineering of low alloy steel. Heat Treatment of Metals 2002; 29: 57-64.

[10] Ma S, Prochazka J, Karvankova P, et al. Comparative study of the tribological behaviour of superhard nanocomposite coatings nc-TiN/a$\mathrm{Si}_{3} \mathrm{~N}_{4}$ with TiN. Surf Coat Technol 2005; 194: 143-8. http://dx.doi.org/10.1016/i.surfcoat.2004.05.007

[11] Miyoshi K, Pouch JJ, Altrovitz SA. Adhesion, friction, and wear of plasma-deposited thin silicon nitride films at temperatures to $700{ }^{\circ} \mathrm{C}$. Wear 1989; 133: 107-23.

http://dx.doi.org/10.1016/0043-1648(89)90117-8

[12] Batan A, Franquet A, Vereecken J, Reniers F. Characterization of the silicon nitride thin films deposited by plasma magnetron. Surf Interface Anal 2008; 40: 754-7.

http://dx.doi.org/10.1002/sia.2730 
[13] Li D, Guruvenket S, Azzi M, Szpunar JA, Klemberg-Sapieha JE, Martinu L. Corrosion and tribo-corrosion behavior of a-SiCx:H, a$\mathrm{SiNx}: \mathrm{H}$ and a-SiCxNy:H coatings on SS301 substrate. Surf Coat Technol 2010; 204: 1616-22. http://dx.doi.org/10.1016/j.surfcoat.2009.10.018

[14] Zhong-rong G, Peng-xun Y, Duo-wang F, Guang-hui Y. Si3N4 nanomicrosphere synthesized by cathode arc plasma and heat treatment. Tras Nonferrous Met Soc China 2009; 19: S718-21. http://dx.doi.org/10.1016/S1003-6326(10)60138-0

[15] Li YS, Shimada S. Synthesis of anticorrosion SiC and SiN x films from alkoxide solution using liquid injection PECVD. Surf Coat Technol 2006; 201: 1160-5 http://dx.doi.org/10.1016/j.surfcoat.2006.01.038

[16] Radwan M, Kashiwagi T, Miyamoto $Y$. New synthesis route for $\mathrm{Si} 2 \mathrm{~N} 2 \mathrm{O}$ ceramics based on desert sand. J European Ceram Soc 2003; 23: 2337-41. http://dx.doi.org/10.1016/S0955-2219(03)00040-2

[17] Raynaud P, Despax B, Segui Y, Caquineau H. FTIR plasma phase analysis of hexamethyldisiloxane discharge in microwave multipolar plasma at different electrical power. Plasma Process Polym 2005; 2: $45-52$

http://dx.doi.org/10.1002/ppap.200400034

[18] Vinogradov I, Zimmer D, Lunk A. Diagnostics of SiCOH-filmdeposition in the dielectric barrier discharge at atmospheric pressure. Plasma Process Polym 2007; 4: S435-9.

[19] Tsujikawa M, Yamauchi N, Ueda N, Sone T, Hirose Y. Behavior of carbon in low temperature plasma nitriding layer of austenitic stainless steel. Surf Coat Technol 2005; 193: 309-13.

http://dx.doi.org/10.1016/j.surfcoat.2004.08.179

[20] Arslan E, Igdil MC, Trabzon L, Kazmanl K, Gulmez T. The corrosion behaviour of austenitic $316 \mathrm{~L}$ stainless steel after low- $\mathrm{T}$ plasma nitridation in the physiological solutions. Plasma Process Polym 2007; 4: S717-20.

[21] Wang J, Xiong J, Peng Q, et al. Effects of DC plasma nitriding parameters on microstructure and properties of $304 \mathrm{~L}$ stainless steel. Mater Character 2009; 60: 197-203.

http://dx.doi.org/10.1016/j.matchar.2008.08.011

[22] Snyders R, Bousser E, Amireault $\mathrm{P}$, et al. Tribo-mechanical properties of DLC coatings deposited on nitrided biomedical stainless steel. Plasma Process Polym 2007; 4: S640-6.

http://dx.doi.org/10.1002/ppap.200731601
[23] Ynag $\mathrm{K}$, Manqi LU. The effect of rare earth element $\mathrm{Ce}$ on microstructure and properties of austenitic 201 stainless steel. J Mate Sci Technol 2007; 23: 333-6.

[24] Dong Y, Li X, Tian L, Bell T, Sammons RL, Dong H. Towards longlasting antibacterial stainless steel surfaces by combining double glow plasma silvering with active screen plasma nitriding. Acta Biomater 2011; 7: 447-57. http://dx.doi.org/10.1016/i.actbio.2010.08.009

[25] Huang ZK, Greil P, Petzow G. Formation of silicon oxynitride from Si3N4 and $\mathrm{SiO} 2$ in the presence of Al2O3. Ceramics Inter 1984;10: 14-7.

http://dx.doi.org/10.1016/0272-8842(84)90017-8

[26] El-Hossary FM, Negm NZ, Abd El-Rahman AM, Hammad M. Duplex treatment of 304 AISI stainless steel using rf plasma nitriding. Mater Sci Eng 2009; 29: 1167-73.

http://dx.doi.org/10.1016/j.msec.2008.09.049

[27] Duan RG, Roebben G, Vleugels J, Van der Biest O. Thermal stability of in situ formed $\mathrm{Si}_{3} \mathrm{~N}_{4}-\mathrm{Si}_{2} \mathrm{~N}_{2} \mathrm{O}-\mathrm{TiN}$ composites. J Euro Ceram Soc 2002; 22: 2527-35. http://dx.doi.org/10.1016/S0955-2219(02)00110-3

[28] Forsich C, Heim D, Mueller T. Influence of the deposition temperature on mechanical and tribological properties of a-C:H:Si coatings on nitrided and postoxidized steel deposited by DC-PACVD. Surf Coat Technol 2008; 203: 521-5. http://dx.doi.org/10.1016/i.surfcoat.2008.05.044

[29] Cullity BD. Elements of X-Ray Diffraction. 3rd ed., Prentice Hall; 2001.

[30] De Las Heras E, Santamarıa DG, Garcia-Luis A, et al. Microstructure and wear behavior of DC-pulsed plasma nitrided AISI 316L austenitic stainless steel. Plasma Process Polym 2007; 4: S741-5. http://dx.doi.org/10.1002/ppap.200731809

[31] Habraken FHPM, Kuiper AET. Silicon nitride and oxynitride films. Mater Sci Eng 1994; R12: 123-75. http://dx.doi.org/10.1016/0927-796X(94)90006-X

[32] Kato K. Tribology of ceramics and hard coatings. Mat-wiss u Werkstofftech 2003; 34: 1003-7. http://dx.doi.org/10.1002/mawe. 200300685 